\title{
Impact of indoor residual spraying on malaria transmission in the Moïssala health district, Chad
}

Israel DEMBA KODINDo ( $\sigma$ iskodindo@yahoo.fr)

National malaria Control Program

Diomba Dobar Abel

National Malaria Control Program, Ministry of Health

Adoum Mahamat Oumar

National Onchocerciasis Control Program, Ministry of Health

Moundai Tchonfinet

National Guinea Worm Eradication Program, Ministry of Health

Amen Nakebang Fadel

National Malaria Control Program, Ministry of Health

Yangalbé-Kalnoné Elise

National Malaria Control Program, Ministry of Health

Brahim Adef Abba

National Malaria Control Program, Ministry of Health

Djédion Belemel

National Malaria Control Program, Ministry of Health

Mallaye Peka

National Human African Trypanosomiasis Control Program, Ministry of Health

Kerah-Hinzoumbe Clément

National Malaria Control Program, Ministry of Health

\section{Research}

Keywords: Malaria, Impact of transmission, Indoor spraying, Moïssala Health District, Sudano-Guinean zone, Chad

Posted Date: January 14th, 2020

DOI: https://doi.org/10.21203/rs.2.19781/v2

License: (9) (1) This work is licensed under a Creative Commons Attribution 4.0 International License. Read Full License 


\section{Abstract}

Backgroud Malaria is a major public health and development problem in Africa. In Chad in 2016, with 720 765 confirmed cases and 1686 deaths, malaria is the main cause of consultations, hospitalizations and deaths in health facilities. A longitudinal entomological study was carried out from 07 to 24 December 2016 in the Moïssala health district. The objective of the study was to assess the impact of malaria transmission one year after two cycles of indoor residual spraying of $80 \%$ bendiocarb wettable powder (Ficam WP 80 W). Methods Two areas were defined for the study: the town of Dembo, located in the sprayed area, was chosen as the test town and Moïssala, located in the untreated area, was chosen as the control town. Two sampling methods were used: collection of resting endophilic fauna and direct capture of aggressive mosquitoes from human subjects. Results A total of 16 sessions of catches on human subjects totalling 32 man-nights were conducted and 160 rooms were sprayed per site. For 160 sprayed chambers per site, two anopheles were captured in Dembo compared to 547 in Moïssala. Three anophelian species have been morphologically identified. In Moïssala, An gambiae sl ( An colluzzii : 96\%, An gambiae : 4\%), An funestus and An rufipes were captured at rest in the rooms and on human bait. In Dembo, the two anopheles, An colluzzii and An funestus were captured at rest in the rooms. On human bait as in endophilic fauna, An gambiae sp was the most common species in Moïssala. The aggressive anophelian density was zero in Dembo while it is 9 bites per man per night in Mosesala. Only Anopheles gambiae sp was found infected in aggressive wildlife. The sporozoite index of the aggressive fauna of An gambiae sp was $7.45 \%$. Malaria transmission was estimated at 0.67 infected bites per man per night, or 244.55 infected bites per man per year. In endophilic fauna, An gambiae sp and An rufipes were the two species found infected in Moïssala with sporozoite indices of $6.70 \%(23 / 343)$ and $20 \%(2 / 10)$ respectively. However, in Dembo, neither of the two captured individuals was found infected. Conclusions The indoor residual spraying campaign in the eastern zone of the Moïssala health district has led to the collapse of the density and aggressiveness of malaria vectors. However, its evaluation over a short period of time is not sufficient to assess the impact of malaria transmission in this stable and highly endemic malaria zone.

\section{Introduction}

Malaria is a major public health and development problem in Africa. In 2016, 216 million cases of malaria were reported in 91 countries, an increase of 5 million from the previous year and the number of deaths reached 445000 . Africa still accounts for $90 \%$ of the associated cases and deaths [1].

However, since its creation, the World Health Organization has always had malaria eradication on its agenda [2]. Efforts have been made to eradicate this scourge in many parts of the world [3]. However, in Africa, eradication is being delayed not only for economic reasons, but also because of insufficient knowledge of how the disease is transmitted in the continent's different ecological areas.

In Chad in 2016, with 720765 confirmed cases and 1686 deaths, malaria is the main cause of consultations (34\%), hospitalizations (30\%) and deaths (35\%) in health facilities [4]. In addition to the 
loss of human lives, malaria is costly in terms of public health expenditures [5].

Divided into three geo-climatic zones that determine three epidemiological facies of malaria, northern Chad is desert with no local transmission [6]. The Sahelian climate center corresponds to an area with unstable malaria due to short seasonal transmission. The south with a Sudanian to Sudano-Guinean climate is characterized by stable malaria, with long seasonal transmission.

Most of the entomological studies conducted in Chad have concerned the Sudanian and Sahelian zone where malaria transmission is attributed to An gambiae sl, An funestus, An pharoensis and An ziemanni $[7,8]$. Yet, to date, no survey has assessed the dynamics of malaria transmission in the transition zone between the Sudanese and Guinean zones. However, the epidemiology of malaria depends largely on the biotope.

Our survey focuses on malaria transmission. It was carried out at the request of the non-governmental organization "Médecins Sans Frontière-France (MSF-France)" to evaluate the effectiveness of the indoor spraying campaign carried out in the eastern zone of the Moïssala health district. Since 2010, MSFFrance has been working in the Moïssala health district in support of the Ministry of Public Health and the National Malaria Control Program. It has developed preventive (awareness, seasonal malaria chemoprophylaxis) and curative (seasonal malaria hospital management unit) activities.

In an effort to strengthen protection against mosquito bites in addition to long-lasting insecticide-treated nets distributed by the Ministry of Public Health, MSF-France considered using Fendona ${ }^{\circledR}$ (a pyrethroid insecticide) for an indoor residual spraying campaign in the eastern zone of the Moïssala health district. The recommendations of the NMCP following a study carried out in 2015 on mosquito susceptibility in the said health district (data presented in another article) finally led to the use of Ficam ${ }^{\circledR}$ (insecticides of the Carbamates class).

The objective of the study is to evaluate the impact of this spraying campaign on the dynamics of malaria transmission in two villages, one (Dembo) in the sprayed area and the other (Moïssala) in the control area. More specifically, this involves determining the aggressive density of mosquito populations and assessing the rate of plasmodial infection of vectors.

\section{Materials And Methods}

\section{Study area and population}

To assess the impact of this campaign, two sites were selected. These are Dembo, located in the sprayed area and Moïssala, which was not treated at all, served as a control.

Moïssala ( $\left.8^{\circ} 20^{\prime} 16^{\prime \prime} \mathrm{N} 17^{\circ} 46^{\prime} 05^{\prime \prime} \mathrm{E}\right)$ is the chief-town of the department of Barh Sara, Mandoul Region. It is located $75 \mathrm{~km}$ from Koumra, the capital of the region and more than $700 \mathrm{~km}$ south of N'Djamena, the capital of Chad. It has a population of approximately 33 098. The city of Moïssala is located on the banks of a permanent river, the Barh Sara, a tributary of the Chari River that originates in the Central 
African Republic. The river can be crossed with a ferry or a canoe. However, during the rainy season and depending on the level of the floods, the crossing with the ferry is not always guaranteed. The alternative is the road for a two-day trip to Dembo.

Dembo is the chief-town of the Dembo Sub-Prefecture in the department of Barh Sara. It is located $25 \mathrm{~km}$ east of Moïssala and about $27 \mathrm{~km}$ north of the border with the Central African Republic. It has a population of approximately 19013 . The city is bordered by a pond (Goumoud) which is watered in the rainy season and dried up in the dry season. During wintering, swamps form between Dembo and Moïssala, making traffic extremely difficult. Sometimes, when the rains are very heavy, the road is impassable throughout the season but this difficulty disappears more or less completely towards the end of the dry season.

The two cities have geographical and cultural similarities. The climate is tropical of the Sudano-Guinean type, characterized by the alternation of a long rainy season, from May to November, and a dry season, from December to April. The average annual rainfall exceeds $900 \mathrm{~mm}$ per year with a maximum of rainfall in August. The average annual temperatures range from $17^{\circ} \mathrm{C}$ in December/January to $40^{\circ} \mathrm{C}$ in March/April. Soils are generally sandy or clayey with a high humus content. In some places, soil impermeability causes swampy areas during the rainy season. The once heavily forested region has undergone intense clearing due to high population pressure.

The forest, which consists of very large trees (fig trees, "caïlcédrats", tamarind trees, Karités, "Nérés", etc.), vines and epiphytic plants, has suffered particularly from human activity, which has largely cleared it to replace it with food crops, but now only remains in the form of highly degraded galleries along watercourses.

The main crops are: sorghum, groundnuts, rice, cassava, cotton, beans, sesame and market gardening. The population is composed of Mbaye, Nar, Gor, Gor, Ngama, Daye and Peulhs ethnic groups. The activities practiced by the population are: traditional rainfed agriculture, fruit growing, animal husbandry, trade and fishing. Large and small livestock are parked at night in enclosures in the vicinity of houses.

Most of the houses are of traditional, rectangular and circular types, with dry clay or brick walls. Their roofs are made of metal sheet or thatch. The population is supplied with drinking water through traditional wells and boreholes equipped with human-powered pumps.

The main diseases of the inhabitants of Moïssala and Dembo are in order of importance from the point of view of the number of cases reported by health facilities: malaria, mainly Plasmodium falciparum, is endemic, malnutrition, measles, meningitis, etc.

Entomological data from the region are non-existent. Both cities use the same vector control methods based on the use of long-lasting insecticide-treated nets widely distributed to all households during the 2014 mass campaign. 
The study took place from $07^{\text {th }}$ to $24^{\text {th }}$ December 2016 in four of the eight districts of the city of Moïssala and in four of the seven districts that make up the city of Dembo (Figure 1).

\section{Methodology}

\section{Sampling techniques}

Mosquito population sampling was carried out by two methods of capture:

1. Direct capture on human bait at night (indoor and outdoor);

2. Intra-domestic spraying of pyrethrum-based insecticide (Red Can®) during the day.

\section{Capture on human}

Aggressive fauna on humans has been studied using the Le Goff et al. method (9). For this method, 3 parameters were determined:

1. The aggressiveness rate (ma) which is the number of mosquito bites per person per night;

2. The sporozoite index (SI) of the captured mosquitoes;

3. The daily inoculation rate $(\mathbf{h}=\mathbf{m a x}$ IS).

The catches were made by volunteers, all young men recruited in each city. These volunteers were previously trained after obtaining their consent. "Men-night" are used both as bait and as captors. They were protected from malaria by Sulfadoxine-Pyrimethamine chemoprophylaxis. Catches were made for four consecutive nights in four neighbourhoods of each site, with one hut per neighbourhood. This corresponds to 16 catch sessions per site, or 32 "men-night". The neighbourhoods were selected according to a peripheral-intermediate-central transect. For each capture point, the consent of the head of the household was obtained for the access of the catchers to their household. For each compound, two catch points are retained. One inside the hut (used as a bedroom) and the other outside. The captures are organized from $6 \mathrm{pm}$ to $6 \mathrm{am}$ by two teams of two capturers each. The first team operates from $6 \mathrm{pm}$ to midnight and the second from midnight to $6 a \mathrm{~m}$.

Volunteers are rotated at each capture session (between teams, capture points and houses) to minimize biases due to their individual ability and attractiveness. Each capturer is equipped with a torch, a watch, hemolysis tubes and bags labelled by time slot and bearing the identification of the capture point. In a practical way, each volunteer, seated on a bench/stool/chair, captures with a hemolysis tube the mosquitoes placed on his bare legs up to his knees. The hemolysis tubes containing the mosquitoes are then placed in bags corresponding to catch time slots.

\section{Capture of endophilic fauna after indoor residual spraying with insecticides}

This method was used for the collection of female endophilic mosquitoes to assess the density of resting mosquitoes in bedrooms. It consists of spraying a pyrethrum solution into bedrooms to collect 
mosquitoes at rest. The insecticides used are commercial products based on $\mathrm{ORO}^{\circledR}$ brand Pyrethroids (permethrin: $0.25 \%$; tetramethrin: $0.20 \%$; d-ferothrin: $0.01 \%$; piperonyl butoxide: $0.34 \%$ ).

Before each spray, white bed sheets were spread to cover the entire floor of the room and the furniture, then an agent protected by a mask and glasses, after closing the door and windows, sprays the room for about fifteen seconds before leaving. After about ten minutes of waiting, the sheets are carefully removed and the lightning-fallen mosquitoes are recovered with the help of pliers in petri dishes bearing indications on the site, the district, the compound and room number. These spraying sessions take place between $6 \mathrm{am}$ and $11 \mathrm{am}$.

\section{Treatment of captured mosquitoes}

Mosquitoes captured by the above methods are identified using a binocular magnifying glass according to the morphological genus and species criteria [10]. Females of anopheles are then counted and classified according to the location, time and method of capture, repletion state of their abdomen (unfed, fed, half-gravid, gravid) and individually deposited in microtubes containing a desiccator (silicagel) for transport and storage. The microtubes are assembled in bags and stored at minus $20^{\circ} \mathrm{C}$ for further analysis at the laboratory of "Laboratoire du Centre de Recherche Entomologique de Cotonou (Benin)". The determination of the circumsporozoite antigen of malaria parasites in mosquitoes was done by the Elisa technique [11, 12]. Molecular identification of An gambiae complex species was performed by PCR SINE 200 according to the protocol of Santolamazza et al [13].

\section{Statistical analysis}

All data recorded on the survey sheets were entered into Microsoft Excel software and transferred to version 20 of the IBM SPSS statistical analysis software. The daily aggressiveness rate (ma) was calculated from the number of bites received per man per night. $\mathrm{m}$ represents the number of mosquitoes per man and $\mathbf{a}$, the daily frequency of bites performed by a female anopheles on a man. The sporozoite index corresponds to the presence in females of anopheles of the circumsporozoite antigen established by ELISA CSP research. This index is estimated in number of infected female anopheles out of the total number of anopheles analysed times one hundred. The daily entomological inoculation rate $(\mathbf{h}=\mathbf{m a s})$ was calculated from the product of the daily aggressive density ( $\mathrm{ma}$ ) and the proportion of females with CSP antigen (s). The daily entomological inoculation rate allows the monthly and annual inoculation rate to be deducted. Anophelian density is the product of endophilic anophelian fauna and the number of rooms sprayed.

\section{Results}

\section{Anopheles species present}

Three anopheles species have been identified in Moïssala in the control area. These are An gambiae sl, An funestus and An rufipes, whereas in Dembo in the treated area, An gambiae s/ and An funestus were 
collected (Table 1).

\section{Molecular forms within the An. gambiae complex}

Of the 386 individuals in An gambiae complex randomly selected and subjected to PCR molecular forms, An colluzzii is $96 \%$ (371/385) in majority compared to An gambiae 4\% (14/385) in Moïssala. In Dembo, the only individual caught belongs to An coluzzii species.

\section{Aggressive fauna}

\section{Time rhythm and aggressiveness rate}

In Moïssala, the aggressiveness of mosquitoes starts from $6 \mathrm{pm}$ and continues throughout the night both indoor and outdoor. There is a high rate of biting between 10 p.m. and 4 a.m., no matter where you are. Inside, the bite peak occurs around 3 a.m. while outside, a high rate is reached earlier, between 10 p.m. and 11 p.m., and a second one between midnight and 1 a.m.

During the four successive night captures, 303 anopheles were captured in Moïssala while in Dembo, the aggressiveness rate was zero for the same number of capture sessions. The 303 anopheles were captured during 16 capture sessions totalling 32 Men-night. The average aggressive anophelian density in Moïssala was 9 bites/man/night (Figure 2).

Anopheles gambiae s/ bites both inside and outside houses. However, $55 \%$ of the females were caught indoors, indicating the tendency of this species to endophagy. On the other hand, Anopheles funestus is exclusively caught outdoors. The distribution of the number of anopheles caught on humans is summarized in Table 2 for each species (Table 2).

\section{Sporozoite indices of aggressive fauna}

The sporozoite antigen indices tested in An funestus and An rufipes were negative. On the other hand, out of a total of 295 Anopheles gambiae s/ randomly selected and observed at Elisa for infection, 22 were found to carry Plasmodium sporozoites, representing a sporozoite index of 7.45\% (Table 3).

\section{The entomological inoculation rate}

The average entomological inoculation rate of Anopheles gambiae s/ in Moïssala during the study period was 0.67 infected bites per man per night, or 244.73 infected bites per man per year.

\section{Time distribution of malaria transmission in Moïssala}

The time aggressiveness of Moïssala's mosquitoes starts from $6 \mathrm{pm}$ and continues throughout the night. However, the schedules of infected bites are observed from $8 \mathrm{pm}$ and persist throughout the rest of the night. However, transmission is null between $6 \mathrm{pm}$ and $8 \mathrm{pm}$ as well as in the early morning. The high 
transmission rate occurs during aggressiveness peaks, reaching an average of a maximum of 5 infested bites per person per night during the survey period

\section{Endophilic fauna}

\section{Density of anopheles per room}

During the capture of the morning residual fauna, 547 anopheles were captured in Moïssala against 2 in Dembo for a total of 160 sprayed rooms per locality, i.e. an average density of 3.41 anopheles per room in Moïssala against 0.01 in Dembo. An gambiae sp is by far the most frequent anopheles at rest during the day in houses in Moïssala, while in Dembo the frequency is equal to An funestus. In Moïssala, An funestus and An rufipes are present in small numbers in the houses but in Dembo, the results of the surveys show the absence of An rufipes.

\section{Sporozoite indices of endophilic fauna}

Considering the small number of An funestus and An rufipes captured, all individuals were subjected to the search for plasmodial infection. On the other hand, of the 547 An gambiae sp collected, 343 were submitted to Elisa for infection detection and 23 were carriers of Plasmodium sporozoite antigens, representing a sporozoite index of $6.70 \%$. Two out of 10 An rufipes were infected with sporozoites, representing a sporozoite index of $20 \%$. None of the 13 individuals in An funestus were found infected.

\section{Discussion}

Effective malaria control is based on an integrated approach of several strategies, $[14,15,16]$. For vector control, prevention of malaria transmission through the widespread use of insecticide-treated nets and indoor residual spraying is recommended [17]. But first, knowledge of the sensitivity of malaria vector anopheles to insecticides and their biting behaviour is required before measures can be deployed and post-deployment evaluation of these measures $[18,19]$. The objective of this study was to assess the impact of the indoor spraying campaign on malaria transmission in the eastern zone of the Moïssala health district after two cycles of bendiocarb spraying. This evaluation was carried out by measuring certain entomological parameters of malaria transmission using methods adapted to the study of vectors.

To better evaluate this campaign, these parameters should have been studied for a year. This would take into account the seasonality of transmission and vector density. For example, the results of our study did not allow us to conclude on the degree of effectiveness of IRS in the short, medium and long term. Moreover, our results also did not allow us to conclude whether the difference in the specific composition between 2015 and 2016 is related to IRS. However, the results obtained could be used as reliable scientific databases for future vector control planning. The IRS coverage rate was over $85 \%$, which reflects a high level of support from the local population. According to WHO, for IRS to have a positive impact on transmission, a coverage rate of $80 \%$ must be achieved. In 2015, five species of Anopheles 
were identified in the Moïssala health district (An gambiae sl, An rufipes, An nili, An pharoensis and An ziemanni), while the 2016 results reported only three species: An gambiae sl, An rufipes and An funestus with a prevalence of An gambiae sl. These results are comparable to those obtained by Kerah et al, [7] in Goulmoun, Diarra et al, [8] in Douguia in Chad and Saotoing et al, [20] in Maroua in Cameroon where An gambiae predominates with $84.5 \%, 87.5 \%$ and $81.79 \%$ respectively during night captures on human bait and in residual morning intradomiciliary fauna. These results could be explained by the similarity of these areas in geoclimatic and ecological terms. The aggressive anophelian density is 9 bites $/ \mathrm{man} / \mathrm{night}$ in Moïssala and zero in Dembo. Moïssala's results are similar to those obtained by Himeidan et al [21] in Sudan, Dossou yovo et al [22] in Bouaké, Ivory coast, who reported aggressiveness of $8.82 \mathrm{bite} / \mathrm{man} / \mathrm{year}$ in Um Salala and 8.9 bite/man/night respectively.) Dembo's results (0 bites/man/night) would be related to the spray effect. On the other hand, Kerah et al [7] in Goulmoun (Bongor) in Chad reported a significantly higher Anophelian aggressiveness of $67 \mathrm{bite} / \mathrm{man} / \mathrm{night}$. The density of endophilic fauna is 3.41 anopheles per room in Moïssala and 0.01 anopheles in Dembo. Similar results were reported by Keïta et al, [23] along the Niger River in Mali where densities were low in the sprayed huts and higher in the control huts. The difference in densities between Dembo and Moïssala is believed to be linked to the widespread use of insecticide-treated mosquito nets and, for Dembo, coupled with indoor residual spraying. The entomological comparison of the treated area with the untreated area in this study confirms the results that indoor spraying leads to a decrease in vector density and aggressiveness, with a significant decrease in malaria transmission [24, 25]. This statement, even if it is not shared by some authors [26, 27], is confirmed during this survey and seems relevant for malaria prevention even in areas of permanent transmission. Concerning this parameter, transmission in the control area is about 0.67 infective bites per person per night. However, it is zero in the treated area. The aggressiveness rate of Anopheles indoors (53\%) is higher than outdoors (47\%). This study corroborates those of Kerah and al [57], Doannio et al, [28] in Ivory coast and Coz and Brengues, [29] in Burkina Faso, who observed a rate of aggression of $55.8 \%$ respectively, significantly higher inside than outside the home.

In Moïssala, Anophelian aggressiveness starts from $6 \mathrm{pm}$ and continues throughout the night both inside and outside the houses. In both cases, a high rate of bite is observed between 8 p.m. and 5 a.m. However, the maximum is obtained inside between 02 a.m and 04 a.m and only decreases significantly after 4 hours. Outside the houses, a high rate was reached earlier, between 10p.m and 11p.m and the second between midnight and 1a.m. This intense activity of anopheles between 8 p.m. and 4 a.m. had already been reported previously in some studies $(28,30)$ while others place it after the second half of the night [31]. These results confirm that the aggression cycle has not been altered by the mere use of nets in absence of spraying. The biting rate decreases from 02a.m outside compared to inside. This decrease in aggressiveness would be due to the drop in temperature in December.

Malaria transmission in the Moïssala health district is due to 2 vectors: An gambiae s/ which has been found infected on human bait inside (7.40\%) and outside (7.09\%) as well as in morning fauna $(6.70 \%)$ and An rufipes. Out of 10 An rufipes captured in the morning fauna and analysed by Elisa CSP, 2 were positive, i.e. $20 \%$ of infected animals. This result does not make An rufipes a secondary vector [10,32] but an excellent one to consider in the transmission of malaria to Moïssala. Our results according to which 
An rufipes is captured at rest in the rooms and on human bait are similar to those observed in Dielmo in Senegal [33] and Dori in Burkina Faso [34]. However, investigations incriminating this species in transmission are rare [35]. Although An funestus is, with An arabiensis, a major vector of malaria in Chad, this species plays no role in the transmission of malaria to Moïssala.

\section{Conclusion}

The indoor residual spraying campaign in the eastern zone of the Moïssala health district has led to the collapse of the density and aggressiveness of malaria vectors. However, its evaluation over a short period of time is not sufficient to assess the impact of malaria transmission in this stable and highly endemic malaria zone. The long-term effectiveness of the indoor residual spraying campaign on malaria vectors and transmission will only be assessed after several years of transmission. In addition, the use of mosquito nets and other control measures should be taken into account in this assessment. Although, this intervention was appreciated and won the support of the target population. However, the high cost of the campaign could undermine the sustainability of the strategy, especially since the population's financial income is suffering as the country goes through a period of economic crisis.

\section{Abbreviations}

$\mathrm{N}$ : North ; $\mathrm{E}$ : East ; ${ }^{\circ} \mathrm{C}$ : degree celsius ; ma : aggressiveness rate ; SI : Sporozoite Index ; $\mathrm{h}$ : daily inoculation rate ; PCR : Polymerase Chain Reaction ; WHO: World Health Organization ; ELISA : Enzyme Linked Immunosorbent Assay ; SPSS : Statistical Package for the Social Sciences ; CSP : Circumsporozoite Protein ; An : Anopheles ; sl : senso latus ; IRS : Indoor Residual Spraying ; PSC : Pyrethrum Spray Catch, $\mathrm{CAH}=$ Human Bait Capture.

\section{Declarations}

\section{Acknowledgements}

This work was supported by the Non-Governmental Organization Médecin Sans Frontière France. We would like to thank the organization very much. We also Acknowledgements for the health district authorities of Moïssala for their administrative support and the residents of Moïssala for participating in this study.

\section{Author's contributions}

$\mathrm{KHC}$ conceived, analyzed the data and coordinated the study. DKI conceived, conducted the study, analyzed the data and drafted the manuscript. DDA, AMO, MT, ANF, YKE, BAA, DB, MP conducted the study and reviewed the manuscript. All authors read and approved the final version of the manuscript.

\section{Funding}


This study was carried out with the financial support of the Non-Governmental Organization Médecins Sans Frontière France.

\section{Availability of data and materials}

The data supporting the conclusions of this article are included within the article.

\section{Ethics approval and consent to participate}

Clearance for field work and ethical approval was granted by the Public Ministry of Health. Prior to collection, a meeting was held with the local chief, the catchers and the village people at Moïssala to explain the aim of the study and its benefits. Indoor collection was carried out only in the houses of people who consented.

\section{Competing interests}

The authors declare that they have no competing interests

\section{Consent for publication}

Not applicable

\section{References}

1. WHO a. Rapport sur le paludisme dans le monde 2017.

2. WHO. Eradication du paludisme. Conseil Exécutif, Cent quarante et unième session. Genève, 18 mai 2018. 5p.

3. WHO. Les Émirats arabes unis certifiés exempts de paludisme. Relevé épidémiologique hebdomadaire. Genève, Organisation mondiale de la Santé, 2007, 4 :30-31.

4. Programme National de Lutte contre le Paludisme. Rapport annuel d'activité. N'Djaména 2017, 28p.

5. Avocksouma DA, Sosso H, Donan-Gouni I, N'Detibaye A, Mbodou A et Souleingar N. Impact socioéconomique du paludisme au Tchad 2002, 32p.

6. Saugrain J, Taupplieb R. Anophélisme sans paludisme au nord Tchad. Bulletin de la Société de Pathologie exotique. Tome 53, n³, Mars-Avril 1960. p150-152.

7. Kerah-Hinzoumbé C, Mallaye P, Nkondjio CA, Donan-Gouni I, Awono-Ambene P, Samè-Ekobo A et al. Malaria vectors and transmission dynamics in Goulmoun, a rural city in south-western Chad. BMC Infectious Diseases 2009, $9: 71$.

8. Diarra AZ, Dabo A, Saye R, Coulibaly D, Guindo MA, Sagara I et al. Entomological and parasitological parameters of malaria transmission in Douguia, Chad. Médecine et Santé Tropicales 2017, 27 : 253259. 
9. Le Goff G, Carnevale P et Robert V. Comparaison des captures sur homme et aux pièges lumineux CDC pour l'échantillonnage des moustiques et l'évaluation de la transmission du paludisme au SudCameroun. Ann. Soc. Belge Med. Trop 1993, 73, 55-60.

10. Gillies MT, De Meillon B. The Anophelinae of Africa south of the Sahara (Ethiopian zoogeographical region). Publication of the South African Institute for Medical Research 1968, 54: 343.

11. Burkot TR, Williams JL, Schneider I. Identification of Plasmodium falciparum-infected mosquitoes by a double antibody enzyme-linked immunosorbent assay. Am J Trop Med Hyg 1984 ; 33 : 783-8.

12. Wirtz RA, Zavala F, Charoenvit $Y$ et al. Comparative testing of Plasmodium falciparum sporozoite monoclonal antibodies for ELISA development. Bull World Health Organ 1987, 65 : 39-45.

13. Santolamazza F, Calzetta M, Etang J, Barrese E, Dia I, Caccone A et al. Distribution of knock-down resistance mutations in Anopheles gambiae molecular forms in west and west-Central Africa. Malar J 2008, 7:74.

14. OMS. Stratégie technique mondiale de lutte contre le Paludisme 2016-2030. Organisation mondiale de la santé, Genève, Suisse 2015. pp39.

15. World Health Organization. Recommendation: Intermittent Preventive Treatment of malaria in pregnancy using Sulfadoxine-Pyrimethamine (IPTpSP). WHO : Genève, 2012. Disponible sur : who.int/malaria/iptp_sp_updated_policy_recommendation_en_102012.pdf. (Consulté le 10 mars 2015).

16. World Health Organization. Recommendation. Achieving universal coverage with long-lasting insecticidal nets in malaria control. WHO : Genève, 2013 (revised March 2014). Disponible sur : http://www.who.int/malaria/publications/atoz/who_recommendations_universal_coverage_llins. pdf. (Consulté le 10 mars 2015).

17. WHO. Action mondiale pour lutter contre les vecteurs 2017-2030. Document de base pour éclairer les délibérations lors de la 70e session de l'Assemblée mondiale de la Santé. Organisation Mondiale de la Santé 2017. Version 5.4. pp62.

18. WHO. Global plan for insecticide resistance management in malaria vectors (résumé disponible en français). Geneva: World Health Organization; 2012 (http://apps.who.int/iris/bitstream/10665/44846/1/9789241564472_eng.pdf, consulté le 10 mars 2015); WHO. Test procedures for insecticide resistance monitoring in malaria vector mosquitoes. Geneva: World Health Organization; 2013 (http://apps. who.int/iris/bitstream/10665/80139/1/9789241505154_eng.pdf, consulté le 10 mars 2015).

19. Najera JA, Zaim M. Malaria vector control. Decision making criteria and procedures for judicious use of insecticides. Geneva, WHO, 2003; document World Health Organization/WHOPES/2002.5 Rev.1.

20. Saotoing P, Fohouo-Tchuenguem FN, Njan Nlôga AM. 2014 - Enquête entomologique sur la faune culicidienne de la ville de Maroua, région de l'Extrême Nord Cameroun. International Journal of Innovation and Applied Studies. 2014; vol.9 № 1 : 438-448.

21. Himeidan YE, Elzaki MM, Kxeka JE, Ibrahim M, Elhassan MI. Pattern of malaria transmission along the Rahad River basin, Eastern Sudan. Parasites Vectors 2011; 4 : 109, Environmental Health Project, 
Activity Report 108, 54.

22. Dossou-Yovo J, Doannio JMC, Diarrassouba S, Chauvancy G. The Impact of Rice Fields on the Transmission of Malaria in Bouaké,Côte d'Ivoire. Manuscrit n 1898.“Entomologie médicale”. Accepté le 24 avril 1998.

23. Keïta K, Keïta M, Sogoba N, Yaro AS, Sangaré D, Keïta A et al. Evaluation de l'impact d'une pulvérisation intra-domiciliaire en saison sèche sur la transmission du paludisme le long du fleuve Niger, Mali. Antropo 2017 ; 38, 87-97. www.didac.ehu.es/antropo.

24. Barutwanayo M, Coosemans M, Delacollette C, Bisore S, Mpitabakana P, Seruzingo D. La lutte contre les vecteurs du paludisme dans le cadre d'un projet de développement rural au Burundi. Ann Soc Belge Méd Trop 1991. 71 (suppl 1): 113-125.

25. Cot M, Brutus L, Le Goff G, Rajaonarivelo V. Raveloson A. Comparison of Lambda-Cyhalothrin and DDt house-spraying for malaria control on the western slopes of Madagascar highlands. II Parasitological and clinical. Parasite, 2001; 8, 309-316.

26. Robert V, Trape J-F. Lutter contre le paludisme en réduisant sa transmission ? Présentation de la controverse. Médecine/sciences 1997; n 5, vol. 13: 678-82.

27. Trape J-F and Rogier C. Combating Malaria Morbidity and Mortality by Reducing Transmission. Parasitology Today 1996; Vol. 12, no. 6.

28. Doannio JMC, Dossou-Yovo J, Diarrassouba S, Rakotondraibé ME, Chauvancy G, Chandre F et al. Malaria transmission in the rice growing area of Kafine village, Côte d'Ivoire. Exot, 2002; 95, 1, 11-16.

29. Coz J, Brengues J. Le complexe Anopheles gambiae et l'épidémiologie du paludisme et de la filariose de Bancroft en Afrique de l'Ouest. Méd. Afr. Noire1967; 6, 301-303.

30. Zoulani A, Carnevale P, Penchenier L. Influence des moustiquaires imprégnées de deltaméthrine sur le cycle d'agressivité d'Anopheles gambiae à Djoumouna, Congo. Ann. Soc. Belg. Méd. Trop, 1994; 8391.

31. Konan YL, Koné AB, Doannio JMC, Fofana D, Odehouri-Koudou P. Malaria transmission in Tiassalékro, a irrigated rice growing village situated in the South forest area of Côte d'Ivoire. Bull Soc Pathol Exot, 2009; 102, 1, 26-30.

32. Hamon J, Mouchet J. Les vecteurs secondaires du paludisme humain en Afrique. In : Etudes sur le paludisme en Afrique Médecine Tropicale, 21 (No spécial), 1996 ; P. 643-660. ISSN 0025-682X.

33. Hamon J, Coz J, Sales S. Ouedraogo CS. Etudes entomologiques sur la transmission du paludisme humain dans une zone de steppe boisée, la région de Dori (République de Haute-Volta). Bulletin de l'I. F. A. N. T 1965 ; XXVII, Série A, no 3.

34. Konate L, Diagne N, Brahimi K, Faye O, Legros F, Rogier C et al. Vectors bionomics and transmission of Plasmodium falciparum, $P$. malariae and $P$. ovale. in a Sudan Savanna area of West Africa (Dielmo, Senegal). Parasite. 1994; 1. 325-333.

35. Holstein M. Un nouveau vecteur du paludisme en A. O. F. Anopheles rufipes Gough 1910. Office de la Recherche Scientifique d'Outre-Mer. Entomologie Médicale et Vétérinaire. 1947 : Code Classement N 379. 


\section{Tables}

Table 1. Results of aggressive and residual morning fauna collection

\begin{tabular}{lllllll}
\hline Study sites & Species & PSC & \% & HBC & \% & Total \\
\hline Moïssala & An gambiae sl & 547 & 95.96 & 295 & 97.36 & 842 \\
\cline { 2 - 7 } & An funestus & 13 & 2.28 & 4 & 1.32 & 17 \\
\cline { 2 - 7 } & An rufipes & 10 & 1.75 & 4 & 1.32 & 14 \\
\cline { 2 - 7 } Dembo & Total & $\mathbf{5 7 0}$ & & $\mathbf{3 0 3}$ & $\mathbf{8 7 3}$ \\
& An gambiae sl & 1 & 50 & 0 & 0 & 1 \\
\cline { 2 - 7 } & An funestus & 1 & 50 & 0 & 0 & 1 \\
\cline { 2 - 7 } & Total & $\mathbf{2}$ & & $\mathbf{0}$ & & $\mathbf{2}$ \\
\hline
\end{tabular}

PSC $=$ Pyrethrum Spray Catch, $\mathrm{HBC}=$ Human Bait Capture

Table 2. Number of species per collection station

Collection station Total

\begin{tabular}{lllll} 
& & Outdoor & Indoor & \\
\hline \multirow{4}{*}{ Species } & An funestus & 4 & 0 & $\mathbf{4}$ \\
\cline { 2 - 5 } & An gambiae sp & 134 & 161 & $\mathbf{2 9 5}$ \\
\cline { 2 - 5 } & An rufipes & 3 & 1 & $\mathbf{4}$ \\
\hline \multirow{2}{*}{ Total } & & $\mathbf{1 4 1}$ & $\mathbf{1 6 2}$ & $\mathbf{3 0 3}$ \\
\hline
\end{tabular}

Table 3. Sporozoite indexes inside and outside the rooms

\begin{tabular}{|c|c|c|c|c|}
\hline & & Elisa CSF & & Sporozoite indexes \\
\hline & & Negative & Positive & $(\%)$ \\
\hline Collection station & outdoor & 124 & 10 & 7.5 \\
\hline & Indoor & 149 & 12 & 7.5 \\
\hline Total & & 273 & 22 & \\
\hline
\end{tabular}


Figures

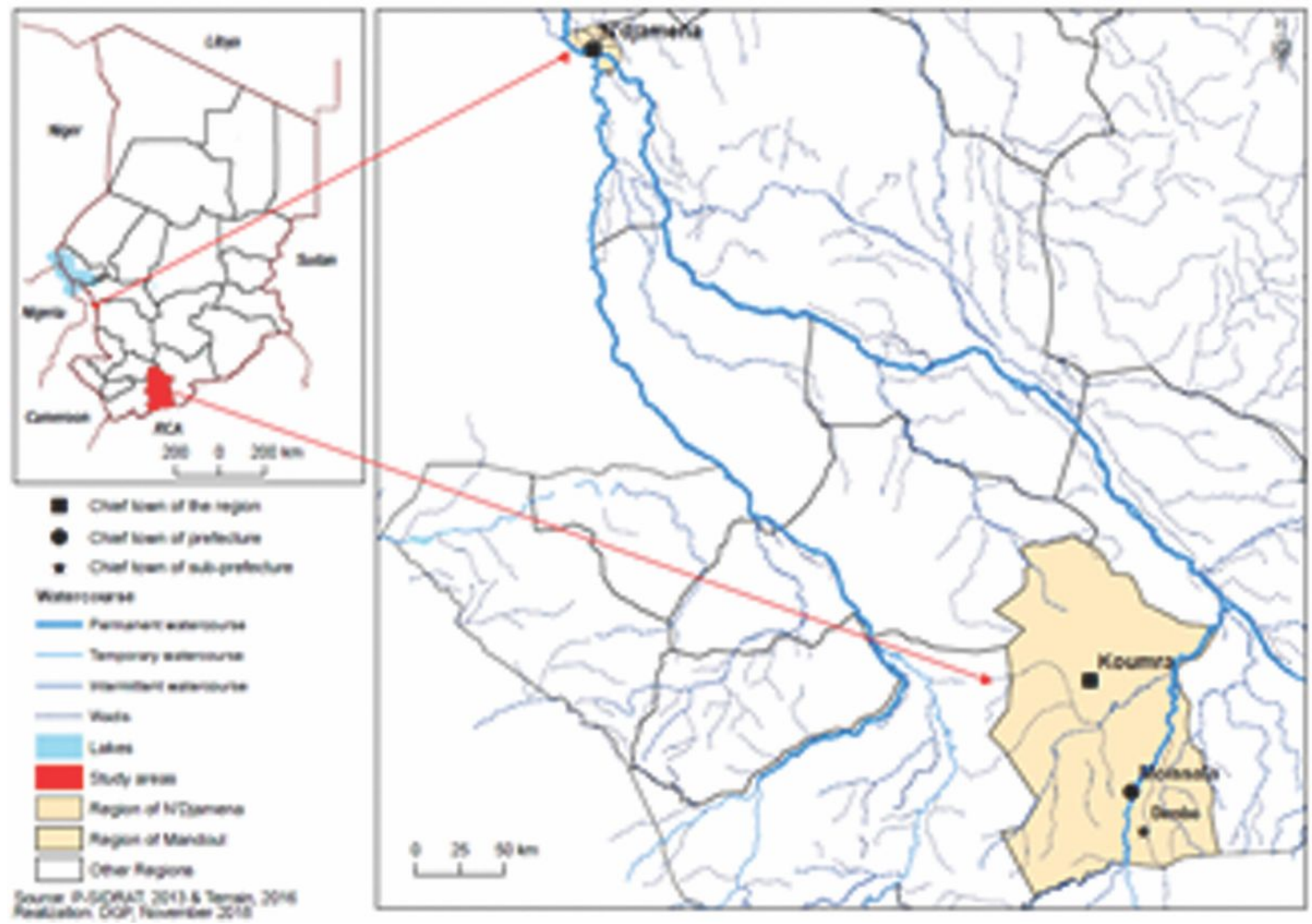

Figure 1

Location of study sites. 


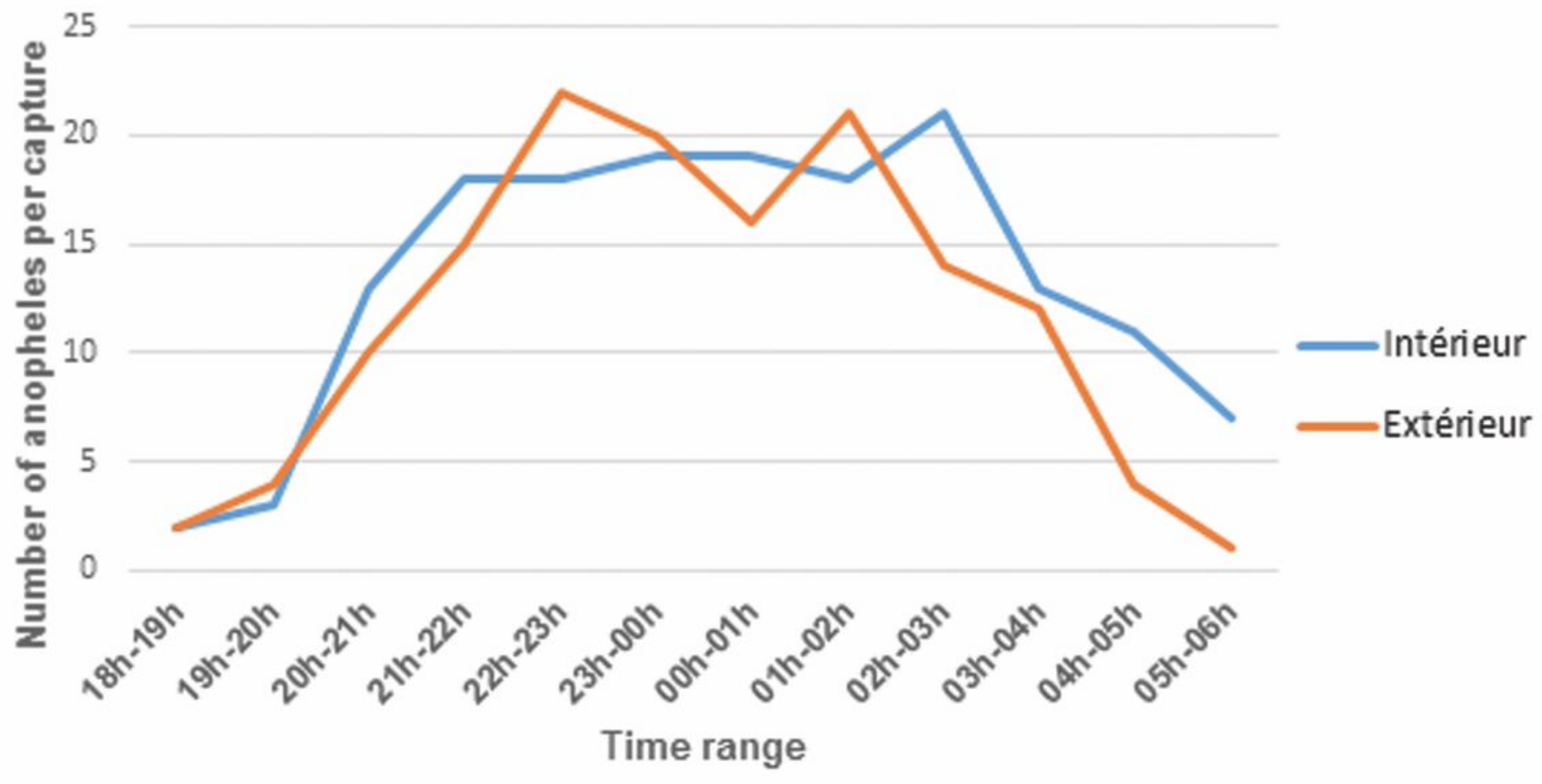

Figure 2

Cycle of time aggressiveness inside and outside the rooms in Moïssala

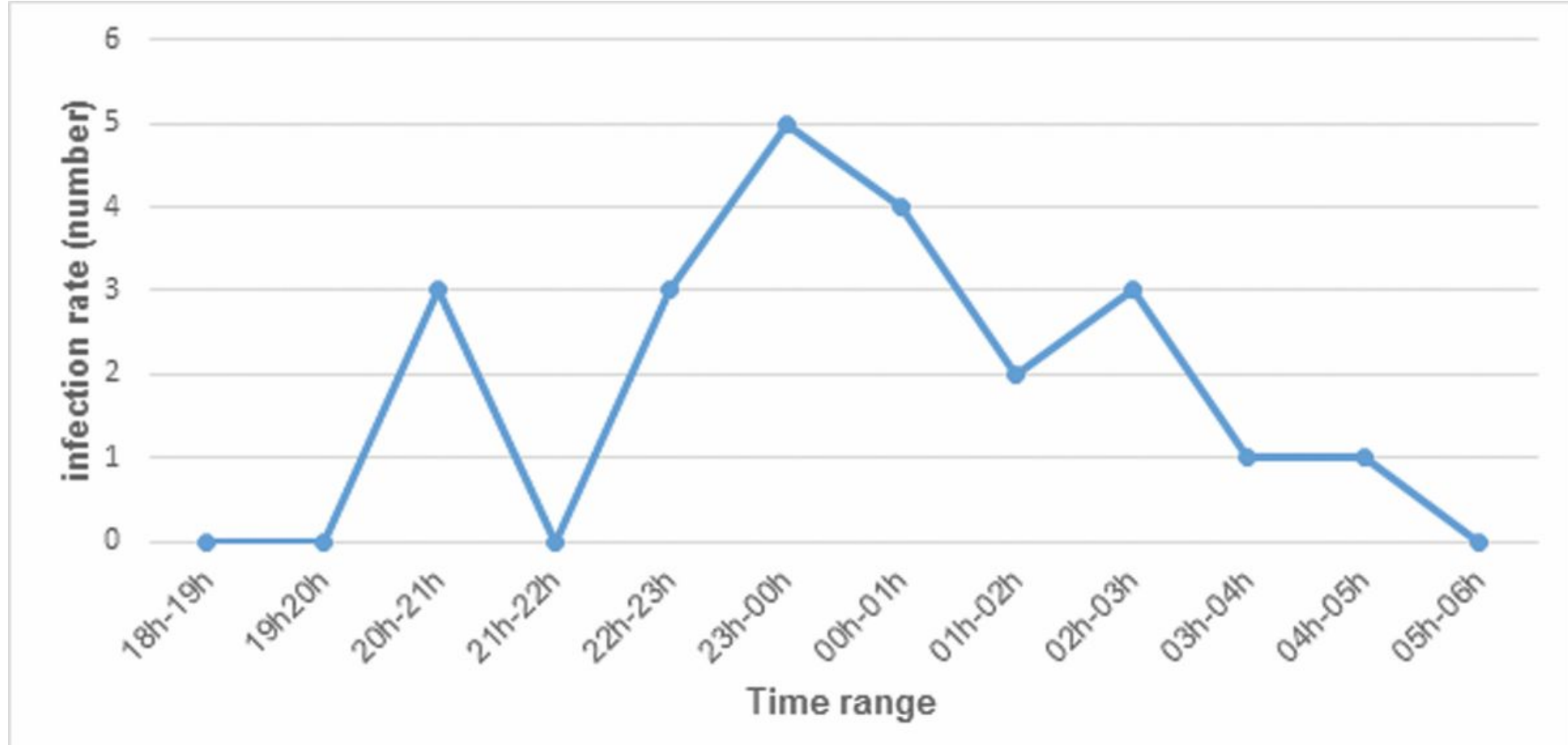

Figure 3

Hourly infection rates 